\title{
Faraizi Movement and Zamindars of Nineteenth Century Bengal: The Story of a Peasant Movement
}

\author{
Nurul Hossein Choudhury
}

\begin{abstract}
The British colonial rule in Bengal had a very ominous impact on the people of the region as a whole. The introduction of a new land tenure system, known as the Permanent Settlement, and the creation of an all-powerful zamindar class particularly affected the interests of the peasants of Bengal. Under the new system, the government demand on the zamindars was fixed in perpetuity, but there was no legal restriction on the zamindars to enhance their share from the peasants. The peasants, consequently, became vulnerable to irregular rent increases and oppressions by the zamindars. The Faraizi movement, organized initially in the nineteenth century to reform the Muslim society, soon assumed the character of agrarian movement. In order to protect the poor peasants, the Faraizis soon became radical and challenged the zamindars. As majority of the peasants of the region, where this movement was launched, were Muslims and their zamindars mostly Hindus, the Faraizis used Islamic symbols to mobilize the Muslim masses. Thus, religion and economy intertwined in shaping such a protest movement in pre-industrial Bengal.
\end{abstract}

Keywords: Peasants, Zamindars, indigo planters, permanent settlement, Haji Shariatallah, Dudu Miyan.

\section{Introduction}

The establishment of British colonial rule in Bengal in 1757 had far reaching consequences. The new rules and regulations introduced by the British East India Company, the new rulers, had transformed the socio-economic life of the people of this region. The Company imposed the new tenurial arrangements (known as the Permanent Settlement) in 1793, to create, among others, a powerful base of political support among the landed classes in India. Following the British example, an attempt was made to create a hereditary landed aristocracy, which would invest in agricultural expansion. The purpose was to create a stable countryside with a prosperous peasantry through the establishment of landlords (Spear, 1984,Vol. II, $4^{\text {th }}$ ed., p. 97). The British made the revenue-collecting zamindar ${ }^{1}$ the absolute owner and revenue collector over the land. As a result, the Permanent Settlement of 1793 vested the zamindars with the proprietary rights of land. Hamza Alavi observed that: "the peasant was dispossessed of the land which now became the 'property' of the zamindar. ... The landlord became the landowner." Under the new system, the government demand on the zamindars was fixed in perpetuity, but there was no legal restriction on the zamindars to enhance their share from the peasants. The 
peasants, consequently, became vulnerable to irregular rent increases, and became destabilized due to their inability to secure ready cash to pay these new, and increasingly severe demands. In protest, the peasants of Bengal started a number of movements primarily to challenge the authority of these zamindars and to protect their own interests. The Faraizi movement was one of such movements that spread in the entire area of the eastern Bengal. It succeeded in attracting a large number of the Bengal peasantry. Although the main purpose of this paper is to analyze the causes and development of the confrontation between the Faraizis and the zamindars of Bengal, it also seeks to examine the ploys adopted by the zamindars to stem the Faraizi movement. An attempt will also be made to assess the nature of the movement, and the methods of mobilization of the Faraizis in the pre-industrial Bengal.

\section{Setting of the Faraizi Movement}

The Faraizi movement, ${ }^{3}$ organized by Haji Shariat Allah (1781-1840) in Bengal in 1818, was intended, at the initial stage, to reform the socio-religious life of the Bengal Muslims. ${ }^{4}$ However, after the death of its founder, the movement assumed the character of an agrarian movement in Bengal. It was under the leadership of Dudu Miyan (1819-1862), the son and successor of Shariat Allah, that the Faraizis became radical and confronted the local zamindars and the European indigo planters. ${ }^{5}$ Although the Faraizi movement was structured to reform Muslim society, gradually it concerned itself with the issues of social inequality and the economic plight of the peasants and artisans of Bengal.

One of the important steps taken by the Faraizis to effect changes in Muslim society was their denunciation of the prevailing caste prejudices among the Bengali Muslims as a greater insult to the spirit and practice of the Islamic ummah (community). The Bengali Muslim community in Shariat Allah's time was broadly divided into two groups -- ashraf (aristocrat) and atrap (low origin). The ashraf, who claimed foreign descent, considered themselves a superior class, and therefore would have no social intercourse with the atrap. ${ }^{6}$ Some high officials and big zamindars came from this group. In addition, there were four supposed social groups -- Syed, Shaikh, Mughal and Pathan. Once again, the principal basis of stratification was foreign in origin. The Syeds claimed to be the descendants of the Prophet's daughter Fatima; the Sheiks from the Arabs; the Mughals from the Mongols; and Pathans from the Afghans. The remaining bulk of the population, who were engaged in cultivation or other occupations, were described as local converts, and therefore constituted the lower class.

The Faraizis made the ideal of equality and brotherhood their major social platform. They insisted upon every Muslim's obligation to render mutual assistance in times of distress, regardless of their economic status. The Superintendent of the Bengal Police, perhaps not fully conversant with Faraizi ideology, reported to the Government of Bengal:

Ferazees were noted as professing to retain only the pure doctrines of the Koran. They asserted complete equality among themselves and the sect was 
confined to the lower classes. They hung together and supported each other in difficulties, looking on the cause of the highest as that of the lowest and of the whole sect; nothing being considered criminal, if done in behalf of a brother in distress. ${ }^{7}$

The principle of Islamic brotherhood as preached by the Faraizis was actually being put into effect by the followers of the movement as the above report asserts. The Commissioner of Dhaka also affirmed that "they [the Faraizis] assert a kind of equality amongst themselves which is no doubt very seductive to the lower classes..." As Khan observed, the principle of Islamic brotherhood did attract the lower order of the Bengali Muslims consisting of the peasants and weavers of Dhaka, Faridpur, Jessore and Bakerganj to the Faraizi movement. ${ }^{9}$ Taylor estimated that Shariat Allah succeeded in converting to Faraizi ideology one-sixth of the population of the districts of Faridpur, Bakerganj, and Mymensingh, and one-third of the Muslim inhabitants of Dhaka (Taylor, 1840, p. 248).

The movement's influence on the rural masses, especially among the lower classes, was remarkable in certain districts, but it could not make any headway in the cities where the Muslim upper classes were the dominant group. ${ }^{10}$ The Muslim upper classes generally preferred to maintain the status quo, as the Faraizi insistence on social equality threatened their own class interests. Their reasons for not joining or supporting the Faraizi movement were thus social as well as economic. Another group, which opposed the Faraizis, consisted of the sabiqi (traditional) Muslims who represented the majority of the Muslim landed gentry. This group had adopted, according to Wise, "the debased Hinduised religion peculiar to Muhammadan [sic] India" (Wise, 1883, p. 7). To them the Faraizi attack on the time-honoured "Muslim caste system" of Bengal was unacceptable. The concept of Islamic unity advocated by the Faraizis among the lower classes, also threatened their vested interests. Nevertheless, a few middleranking Muslim landowners, or jotedars, among the sabiqis, who had considerable influence over the Muslim peasants in the rural areas, joined the Faraizi movement in order to further their own personal interests. By doing so, they had hoped to use its collective strength to counter the influential zamindars, most of whom happened to be Hindus (Ahmed, 1981, p. 44).

As mentioned earlier, the Permanent Settlement had provided an opportunity for the zamindars to collect extra-legal and increased taxes from the peasants. The Muslim zamindars, like their Hindu counterparts, extorted their Muslim peasants (Hardy, 1972, pp. 50-60). They were concerned about the Faraizi activities which bred solidarity among the peasants, and which "bound the Muhammadan [sic] peasantry together with one man" (Wise, 1883, p. 22), So, far, the zamindars had faced little difficulty in extracting illegal cesses from the peasants, since there was no united resistance from the latter. The Faraizi efforts to establish social equality among the peasants of eastern Bengal, based on the doctrines of Islam, generated great enthusiasm among them; it transformed them into a viable social force. The zamindars, whether Hindu or Muslim, became fearful that such a force could be diverted to resist their illegal exactions. Such a realization led the zamindars to hinder the progress of the movement. One of the policies of the Muslim zamindars was to discourage the Muslim tenants from joining 
the Faraizis on religious grounds. Not surprisingly, the zamindars employed religious means to nullify the movement. They employed mullahs (rural priests) to issue a fatwa (religious decree) declaring the activities of the Faraizis as un-Islamic, and therefore Muslims should not join them (Hunter, 1868, p.109).

The Hindu zamindars, like their Muslim counterparts, adopted a strategy to thwart the Faraizi movement. Following the Muslim zamindars, they fell back on religion to deal with the Faraizis. In this case, they appealed to the religious sentiments of the Hindus to stem the rising tide of the Faraizis. The Hindu zamindars depicted the Faraizi activities as a threat to their physical existence and their religion. In a letter to the editor of a local newspaper, the Darpan, they complained: "some evil persons belonging to the group of Shariat Allah created problems for Babu Tarinicharan Majumdar of the village Patkanda in the district of Faridpur by causing obstruction to the worship of gods and goddesses". The zamindars feared that if Shariat Allah was allowed to evangelize his message to the Muslim peasants, the Hindu religion would be endangered (Bandopadhyay, 1940, pp. 311-312). The above letter obviously does not allude to the illegal cesses extracted by the Hindu zamindars but focuses only on religious issues. Their projection of the Faraizi movement as anti-Hindu may have had some impact on their Hindu peasants. Their anti-Muslim propaganda, together with Shariat Allah's insistence on adherence to Islamic doctrines on the part of the Muslim peasants, prevented a majority of the Hindu peasants from actively participating with their Muslim counterparts in the movement against the zamindars' illegal dues. The Hindu peasants, with the exception of a few, did not offer a joint Hindu-Muslim front against the zamindars during the entire period of the Faraizi movement. Nevertheless, they did not actively oppose the Faraizis' struggle against the zamindars or the planters.

The attempts of the Muslim and Hindu zamindars to malign the movement and use religious sentiment in order to prevent the peasants from joining the movement did not succeed. On the contrary, the movement provided the Muslim peasants with an effective medium through which to seek redress for their grievances.

It is apparent, however, that through a religious ideology, which stressed social justice, Haji Shariat Allah was dealing with the problems of economic hardships of the peasants. The inability of the peasants to pay illegal cesses imposed by the zamindars was often severely dealt with by the latter. The Faraizi movement itself during Haji Shariat Allah's lifetime underwent a gradual transformation. It was initiated as a religious reform movement, but, while working among the poor masses, Shariat Allah could not overlook the deep-rooted economic problems that confronted them everyday. To save his poor peasant constituency from what he considered to be spiritual and economic degradation, Shariat Allah was compelled to oppose the zamindars. His challenge to the zamindars was, in effect, a challenge to the Raj that had created them. Mujeeb rightly suggested that "because of its [the Faraizi movement's] opposition to exploitation it also worked for the establishment of a political nucleus" (Mujeeb, 1968, p. 15). 


\section{Faraizis Confront the Adversaries}

As the movement progressed, it began to challenge the zamindars and the colonial rulers as well. It was therefore natural that the colonial government, in order to protect the interests of the zamindars, would support any measure to stem the growing popularity of the Faraizi movement. As a result, the zamindars launched a campaign against the Faraizi leader, Dudu Miyan. They felt that the best way to weaken the movement would be to put him in prison. In his petition to the Governor-General of India, Dudu Miyan provided a list of accusations made against him that the local zamindars, in connivance with the English indigo planters had used to harass him. He wrote:

In 1248 [1846 A.D.], Mr. Dunlop [the indigo planter] broke the haut at Daora and established another haut at Cassimpore. Your Petitioner had no concern with this haut and he was then at Dacca. Your Petitioner's opponents however thinking the above your Petitioner's own doing, with a view of punishing him, purchased the dead body of a man who had died of Cholera, and charged your Petitioner to the effect that while in his house at Bahadoorpore, his disciples had killed the man with blows. ${ }^{11}$

This incident of victimization, first by the combined forces of the local zamindars and the indigo planter, and later the local judicial official, went a long way in shaping the character of agrarian relations in rural Bengal. It confirmed the Faraizi view that justice could not be obtained in colonial law courts against the zamindars and the indigo planters.

\section{Faraizi Methods of Mobilization}

In response to the concerted actions of the zamindars, the planters, and the government officials, the Faraizis decided to mobilize the rural masses. This was initiated in order to politicize the masses through their participation in the policy-making process and direct action. Their modus operendi was ingenious. They opted consciously for direct participation with a view to influencing and winning over the masses. In order to make the Faraizi movement a cohesive political force, Dudu Miyan extended his networks into the remote corners of the rural areas and delegated responsibilities to his khalifas or deputies.

The Faraizis had their own law courts. Dudu Miyan received applications and complaints, and as his chief magistrate, adjudicated disputes between his followers. For punishment, he generally fined the guilty party; or sometimes ordered the party to feed fellow Muslims as an act of atonement; or ordered them to be beaten by shoes. In villages neighbouring his headquarters, Dudu Miyan appointed a munshee over each five or seven villages to decide civil and criminal disputes among his disciples. ${ }^{12}$

The Faraizis discouraged anyone (including non-Muslims) living within the locality, which fell under their influence, to bring any case involving the Faraizis to the government law courts 
without prior permission of the ustad, or the khalifahs. They advised that such cases be taken to the Faraizi courts, but those who resorted to the government law courts were not punishable. However, if the decisions were viewed as going against the interests of the Faraizis, they were resisted by the latter. ${ }^{13}$

Although the Faraizis were opposed to taking any suit to the government law courts, there were occasions that required them to appear before these courts. Under such circumstances, especially when a zamindar attempted to enforce his right against any member of the Faraizis through court, the latter would try to intimidate their opponents. In such cases they used the lathials (militia corps) -- a group composed mostly of Muslims, and partly of Hindus and native Christians, ${ }^{14}$ and equipped with firearms. ${ }^{15}$ Occasionally, the lathials were also known to plunder the property of the zamindars when the latter mistreated the peasants. The zamindars, in turn, took legal action both against the lathials and the peasants. The Faraizis covered their legal expenses by taking a collection of funds from their members. To save a fellow Faraizi, they would also not hesitate to give false evidence before a judge. The Superintendent of Police reported:

Their [Faraizis'] esoteric doctrines are, however, that an oath before a Judge, not of their sect or religion is not legal, and that before such a tribunal it is right to deviate from the truth to favour or aid a Brother. ${ }^{16}$

The organizational network introduced by Dudu Miyan, along with the loyalty he claimed from his followers, made him, according to Beveridge, 'the defacto ruler of Bengal'. Beveridge stated that he "executed more influence than any judge or magistrate in the district of Bakergonj" (Beveridge, 1876, p. 87). Dudu Miyan rejected the administrative system introduced by the colonial government on the ground that it did not protect the interests of the rural masses. In its place, he introduced one of his own, which controlled the temporal and spiritual lives of the members through the Islamic notion of equality and social justice. The indigenous judicial system innovated by the Faraizis was deemed sufficient to protect their interests. It was an attempt on the part of the Faraizi leadership not only to establish control over each of its constituent members, but also to shape his/her life in a prescribed Faraizi tariqah (way). Faraizi leadership attempted to secure the autonomy of their own affairs with minimum interference from the government, the zamindars, and the indigo planters. In this, the ultimate goal was to create a parallel government, which would co-exist with the colonial system.

\section{Faraizi Action Plan: Non-Cooperation}

In their struggle against the zamindars, the Faraizis mobilized the masses through a noncooperation movement, calling upon the peasants not to pay illegal taxes imposed by the zamindars. ${ }^{17}$ The zamindars had adopted various coercive measures to punish individuals for the non-payment of these taxes. Describing the oppressive character of a typical Bengali zamindar, a contemporary author noted: 
Unscrupulous in his [zamindar] character, he did not hesitate to have recourse to any means, however illegal or dishonourable, to screw out of his raiyats [ryots or peasants] as much money as he could. Of the Haptam [Act VII of 1812] and the Pancham [Act V of 1799] he often took advantage; and many were the raiyats who were ruined by his oppression (Day, 1874, pp. 260-261).

Under the influence of the Faraizis, the peasants were brought together, then advised and encouraged to resist all kinds of illegal cesses. ${ }^{18}$ Haji Shariat Allah, Dudu Miyan's father, was the first social reformer in Bengal, who called for the non-payment of illegal taxes. When he asked the peasants of Ramnagar (a village in the district of Dacca-Jalalpur) to stop paying illegal dues to the zamindar, a bitter confrontation between Shariat Allah and the zamindar resulted. Not surprisingly, the police intervened in favour of the zamindar. In the court case that followed, a few of the Faraizi leaders, who had instigated the peasants of Ramnagar, were sentenced to one year's imprisonment with hard labour, and each was fined Rs.200. Shariat Allah himself was apprehended, but was subsequently released on a security of Rs.200, as no witness came forward to testify against him. ${ }^{19}$

Shariat Allah articulated his policy of non-payment of rents in the period near the end of his life, and had little time to follow it up. It was his son, Dudu Miyan, who made the non-payment of illegal taxes an important issue in his movement against rural oppression. Dudu Miyan unequivocally criticized the zamindars' practice of levying illegal taxes. He even complained about Hindu zamindars, who were in "the habit of exacting money from Musalman raiyats [ryots or peasants] on account of Dusserah [durga puja] and other Pujahs." He remarked:

The contribution of money by Mussalmans to Hindu Pujahs and ceremonies is held reprehensible by their religion and is accordingly prohibited, since the contributor identifies himself by his contributions with the actions of the coffers [infidels]. ${ }^{20}$

Dudu Miyan's reformist social policy was to oppose the zamindars, whether Hindu or Muslim, in their exploitation of poor Muslim peasants. He did this skilfully by appealing to their religious sentiments. He justified his call on the peasants not to pay illegal cesses by citing religious sanctions against such payments. He declared: "the earth is God's and that no one has a right to occupy it as an inheritance, or levy taxes upon it." He advised the peasants to "settle on the Khac Mahal [lands which government managed and collected revenue directly], ... and thus escape the payment of any taxes, but that of the land revenue, claimed by the State" (Wise, 1883, p. 24). In doing so Dudu Miyan questioned the rights of the zamindars to collect any illegal taxes other than land revenue. By advocating that the peasants pay the government directly, he in fact challenged the validity of the colonial land tenure system. Therefore, the government had every reason to be concerned with the activities of the Faraizis.

Although Dudu Miyan opposed the exaction of illegal taxes, he did not object to the levying of lawful ones. He carefully formulated a programme that would appeal to the masses. He reaffirmed the popular belief, presumably passed through oral tradition, that the peasants of 
Bengal once enjoyed proprietary rights and paid only revenue. His understanding of the precolonial land tenure system was based on the assumption that, in pre-colonial system, the government owned land and the cultivators paid only the land revenue. The system was in fact much more complex than he had assumed. Dudu Miyan had emphasized the particular aspect of a system, which, he thought, would benefit the peasants. It underlined his preference for payments to the government and not to the zamindars.

By calling upon the peasants to withhold payment of illegal rents, the Faraizis recorded their opposition to any such extortion and reminded the government of its moral obligation to them. Their call posed a threat not only to the zamindars, but also to the colonial government, which depended on the zamindars for peace and stability in rural areas -- and which would ensure the uninterrupted collection of revenues. Both Shariat Allah and Dudu Miyan encountered hostility from the zamindars and the colonial administration.

\section{Faraizi Action Plan: Violence}

It was estimated by government sources that Dudu Miyan had gathered about 80,000 followers, ${ }^{21}$ although the Faraizis themselves put their number between 200,000 and 250,000. ${ }^{22}$ As his followers increased in number, Dudu Miyan became a household name in the districts of Faridpur, Pabna, Bakerganj, Dhaka, Noakhali, Nadia and Jessore. ${ }^{23}$ Faraizi influence even penetrated government circles, and consequently, the government had to take legal actions against a number of Muslim police personnel who were known to have joined the movement. ${ }^{24}$ In due course, Dudu Miyan's influence spread over the entire region of eastern Bengal and the Faraizis were acknowledged as a powerful socio-political force throughout rural Bengal.

In order to streamline the large number of followers into a cohesive force, Dudu Miyan instituted a hierarchical organization. It was he, rather than his father, who used his organizational skill to mobilize the Faraizis as a socio-political force. The socio-economic programmes of the Faraizis became so popular that thousands of poor peasants joined the movement. To prevent the peasants from joining the movement, the zamindars and the planters resorted to coercive measures. The Faraizis, determined to protect their rights, fought back, often with their lathials. Thus, it was no longer an issue between the zamindar and the peasants, but between the Faraizi community and the establishment. Consequently, rural Bengal became a scene of perpetual conflict, involving attacks and counter-attacks between the Faraizis and those with vested interests. Confrontation was inevitable. The Faraizi attempt at establishing judicial autonomy was a threat to the power and influence of the zamindars and the planters. It was also a challenge to the colonial system. The government could not accept the parallel administration as put into practice by the Faraizis.

As was seen earlier, Shariat Allah was under the ban of the police for calling upon his followers to refuse to pay illegal rents. A contemporary source also indicated that he was in custody more than once for inciting his followers against their adversaries (Taylor, 1840, p. 250). 
Curiously enough, James Wise, another contemporary authority, observed: "during [Dudu Miyan's] father's lifetime the sect [the Faraizis] had never opposed or come in contact with the law of the land" (Wise, 1883, p. 24). Shariat Allah's anti-zamindar stand functioned on a limited scale, and may have failed to impress Wise, who was making a comparative assessment between Shariat Allah and his son, Dudu Miyan. No one can deny that the Faraizi movement assumed greater strength under Dudu Miyan. One must also accept the fact that Haji Shariat Allah, as the founder of the movement, had only limited support, but set the stage for the future struggle before he died. In 1838, when Shariat Allah was still alive, a Faraizi attack (Wise calls it a riot), led by Dudu Miyan "assumed at one time a very threatening aspect," and a detachment of the British military had to be sent from Dhaka to bring the situation under control (Wise, 1883, p. 25).

The Ghose and the Sarkar families of Faridpur were among the zamindars, who played a leading role in the fight against the Faraizis. These families resorted to torture in order to prevent the peasants from joining the Faraizis. As mentioned earlier, they also imposed cesses for celebrations of kali puja and durga puja. When the peasants refused to pay these cesses, the zamindars came up with the "beard tax". The subsequent refusal to pay was followed by more physical torture. In 1841, with Dudu Miyan at the head, a few lathials marched against the Sarkar family. The frightened zamindar agreed to cease physical torture and the collection of illegal cesses (Khan, 1965, pp. 38-39).

The next target of Dudu Miyan's campaign in 1842 was the Ghose family. According to a police report:
A body, stated at no less than 800 Ferazees, the raieuts [ryots or peasants] of one Joynarain Ghose, collected together, attacked his bareh [residence], plundered it of every thing, and carried off his brother Muddun Narain Ghose. $^{25}$

Plundering may not have been the primary agenda of the Faraizis, although one should not be surprised if the peasants had taken advantage of the situation. Primarily, this attack against the Ghose family was to protest oppressions the peasants underwent. Even the Superintendent of Police acknowledged:

They were not instigated by a desire of plunder, but of revenge for the oppression and extortion practised on them by this Zemindar, and if a tenth part of what they say, after their conviction, stated to me in a petition extenuating their conduct, was true, I am only surprised that a much more serious and general disturbance did not occur. ... I have no doubt, however, of the general truth of the statements, and the Zemindar appeared to have done every thing which could degrade these men, their religion and their females. ${ }^{26}$

Following this incident, 117 persons were arrested, of whom 106 were tried; 22 of them received 7 years rigorous imprisonment. ${ }^{27}$ Dudu Miyan, one of the accused, was released for lack of 
evidence (Khan, 1965, p. 39). After this incident, he emerged as a charismatic and powerful leader. The two campaigns against the zamindars helped him earn fame as a champion of the cause of the poor. While it was encouraging news for the Faraizis, it was equally threatening to the zamindars and the English planters.

As long as Dudu Miyan was alive, whether inside or outside jail, the Faraizi movement continued to gain strength. It was with his death in 1862, that the Faraizi movement lost much of its momentum and became highly localized in the districts where it had a sizable presence. As Kaviraj puts it:

Because of the absence of a strong centre, the movement became loose ... the movement generally took on the colour of sporadic and isolated actions against landlords, particularly in places where the Farazis had their traditional centres (Kaviraj, 1982, p. 82).

The movement did weaken temporarily after the death of Dudu Miyan, as suggested by James Wise and Narahari Kaviraj, ${ }^{28}$ but stabilized and continued to succeed in checking zamindari outrages, along with infusing a sense of urgency in the colonial government regarding a change in rent laws. Whenever there was an issue that affected the interests of the peasants, the Faraizis were quick to mobilize the rank and file of the peasantry.

Despite these successes, the centre of the Faraizi movement became localized in the southern districts of East Bengal; whereas, during the lifetime of Dudu Miyan, the movement had spread to almost all parts of eastern Bengal. It has been suggested that the southern districts of Bengal were generally exposed to hazardous natural conditions due to the frequent occurrences of cyclones and tidal waves. The people of this region are considered tougher and more turbulent than those in other regions. ${ }^{29}$ It is no wonder that the Faraizi ideology of solidarity and resistance found ready acceptance with the people of that region.

In the 1860 s, and the subsequent decades, the Faraizi solidarity was also used by enterprising Muslim peasants or the jotedars of the southern districts to protect their rights over the new land known as char in the deltaic region. The char lands periodically sprang up when the water level dropped, and it was a hazardous task to bring them into cultivation. When agricultural exploitation of these new lands began, the neighbouring zamindars would often attempt to establish their zamindari rights over them, even though there had never been any cultivation before. The jotedars naturally found it unfair and difficult to accept that the zamindars had rights to these lands. Under the umbrella of the Faraizi movement, the jotedars fought to protect the fruits of their hard earned labour.

The ideology of the Faraizi movement was tailormade to the needs of Muslim agricultural entrepreneurs who were determined to retain the fruits of their enterprise, by violent action if necessary (Ray, 1979, pp. 244-245). 
The jotedars' aspirations to establish a kind of economic autonomy over char lands sometimes led them to support and employ the Faraizis. This would, at least, partly explain the success of the Faraizis in the southern districts.

Contrary to some suggestions that the movement was basically directed against Hindu zamindars ${ }^{30}$ it is evident that both Hindu and Muslim zamindars were equally concerned about Faraizi activities. The oppressed peasantry "broke into the houses of Hindu and Muslim landlords with perfect impartiality." ${ }^{31}$ In some cases, the Muslim zamindars had to pay more heavily than their Hindu counterparts.

\section{Conclusion}

The Faraizi movement, though launched to reform the Bengali Muslim society, soon assumed the character of an agrarian movement. The majority of the peasants of eastern Bengal, where the movement entrenched itself, were Muslims, thus providing a unique opportunity for the leaders to use Islamic ideology for their mobilization. The leaders' ingenious methods of creating an alternative judicial system and proving protection against the tyrant zamindars and indigo planters, created a strong sense of togetherness among the Faraizis. It was evident that religious symbols were employed to vent the economic grievances of the peasants. Thus, the stage was set for the leaders to galvanize the rural masses into a significant movement. As social inequality, economic hardship and coercion were at the heart of the movement, it could be regarded as one the social protest movements in pre-industrial Bengal.

\section{End Notes}

${ }^{1}$ In 1765 when the East India Company Received the diwani or the right to collect revenue, a group of people known as zamindars received ten percent of the revenue they collected from the peasants and deposited the rest to the government. M. Mufakharul Islam. (2012). An Economic History of Bengal, Dhaka: Bangladesh. 1757-1947. 101.

${ }^{2}$ Hamza Alavi. (1980). India: Transition from Feudalism to Colonial Capitalism. Journal of Contemporary Asia, 10(4), 371; B. H. Baden-Powell. (1895). Permanent Settlement of Bengal. English Historical Review, $x, 285$.

${ }^{3}$ The movement came to be known as Faraizi as it insisted upon the faraid, the religious duties of the Muslims.

${ }^{4}$ Bengali Islam was characterized by the blend of local practices and rituals with Islam. Such an amalgamation resulted in the emergence of a kind of folk religion which appeared to many as a deviation from the original Islam. For details see James Wise. (1894),. The Muhammadans of Eastern Bengal. Journal of Asiatic Society of Bengal, LXIII, Part III, (1); A. R. Mallick. (1961). British Policy and the Muslims in Bengal. Dacca. 1757-1856. 
${ }^{5}$ Indigo was cultivated in northern and western India during the ancient period. But its cultivation was introduced in Bengal towards the end of the eighteenth century by the European planters. The planters forced the peasants to cultivate indigo regardless of market price. Instead of redressing the grievances of the peasants, the colonial legal system favoured the legal rights of the planters. The coercion of the planters and discriminatory policy of the colonial government forced the peasants to organize a resistance movement against the European indigo planters in the middle of the nineteenth century. For details see Nurul H. Choudhury. (2001). Peasant Radicalism in Nineteenth century Bengal: The Faraizi, Indigo and Pabna Movements. Dhaka: Bangladesh; B. B. Kling. (1966). The Blue Mutiny: The Indigo Disturbances in Bengal. Philadelphia: USA. 1959-62.

${ }^{6}$ See Imtaz Ahmad. (1966). The Ashraf-Ajlaf Dichotomy in India. Indian Economic and Social History Review, III(3).

${ }^{7}$ Selections from the Records of the Bengal Government Vol. xlii: Papers Connected with the Trial of Moulvie Ahmedoollah of Patna and Others for Conspiracy and Treason. (Calcutta: 1866), p. 141.

${ }^{8}$ Dunber, the Commissioner of Dacca to the Government of Bengal. Bengal Judicial Proceedings, April 7, 1847, No. 99.

${ }^{9}$ M. A. Khan. (1964). Religious Doctrine of the Faraidis. Journal of the Pakistan Historical Society, XII(I), 57.

${ }^{10}$ Jagadish. N. Sarker. (1967). Islam in Bengal. In N. K .Sinha (Ed.), The History of Bengal, Calcutta: India, p. 583.

${ }^{11}$ Petition of Mohsinuddeen Ahmud, otherwise called Doodoo Meea, of Bahadoorpore, Furreedpore, Dacca, to His Excellency the Governor-General of India in Council, March 14, 1859. Bengal Judicial Proceedings, March 31, 1859, No. 223. See Appendix B.

${ }^{12}$ Translation of Proceedings Held in Two Cases Tried in 1847 before the Session Judge of Dacca in which Doodoo Meea and His Followers, Belonging to the Sect of Hadjees or Ferazees were Charged with Unlawful Assemblage, Attended with Wounding, Plunder, Arson \& C. (Calcutta: 1848). pp. 2932. Hereafter Trial of DOOdoo Meea and His Followers.

${ }^{13}$ James Wise, Notes on Eastern Bengal, op. cit., p. 25; The Trial of Doodoo Meea and His Followers, op. cit., p. 31; M. A. Khan. (1965). History of the Faraidi Movement in Bengal, 1818-1906. Karachi: Pakistan. pp. 110-111.

${ }^{14}$ The Trial of Doodoo Meea and His Followers, op. cit., p. 65.

${ }^{15}$ From the Superintendent of Police, Lower Provinces, to F.I.Halliday, Secretary to the Government of Bengal, dated April 20, 1839. Bengal Judicial (Criminal) Proceedings, April 30, 1839, Nos. 66-70; The Trial of Doodoo Meea and His Followers, op. cit., p. 65. 
${ }^{16}$ From the Superintendent of Police, Lower Provinces, to F.I.Halliday, Secretary to the Government of Bengal, Judicial Department, No. 1001, dated Dacca, May 13, 1843. Bengal Judicial (Criminal) Proceedings, May 29, 1843, No. 25, para 8.

${ }^{17}$ The zamindars were allowed to collect legal taxes from the ryots. The rights were given to them by various British Acts. However, they went beyond the limits of those Acts and generally extracted more than the legal dues. Contemporary sources indicate that the zamindars imposed extra-legal cesses on the occasions of their sons' or daughter's marriages or their nephew's "first rice-eating ceremony". For details see Bankimchandra Chatterjee. (1986). Sociological Essays: Utilitarianism and Positivism in Bengal, translated and edited by S. N. Mukherjee and Marian Maddern. Calcutta: India, pp. 113-158; Lal Behari Day. (1874). Govinda Samanta or the History of the Bengal Raiyat. London: England, pp. 256262 and M. A. Khan, History of the Faraidi Movement in Bengal, op. cit., Appendix 'C'.

${ }^{18}$ Calcutta Review, 1844, I, 215-216.

${ }^{19}$ Bengal Judicial (Criminal) Proceedings, April 3, 1832, No.6.

${ }^{20}$ Petition of Moulvy Mohessuddin Ahmed called Doodoo Meah, to J. P. Grant, Secretary to the Government of Bengal, dated Dacca, January 1, 1850. Bengal Judicial (Criminal) Proceedings, January 23, 1850, Nos. 60-61. Also see James Wise, Notes on Eastern Bengal, op. cit., p. 24. The exaction of idolatrous taxes by the zamindars could even lead to violence. The Superintendent of Police of Bengal warned that "the Magistrates must keep a strict watch, not only over these people [Faraizis] but also over the zemindars, particularly of the Hindoos as the latter are very apt resist the non-payment of these men of puja expenses etc., which they consider encouragement of idolatry, by the very gross ill-treatment". Calcutta Review, I, 1844, 216.

${ }^{21}$ Selections from the Records of the Bengal Government, Vol. xlii: Papers Connected with the Trial of Moulvie Ahmedoollah of Patna and Others for Conspiracy and Treason. Calcutta: Alipore Jail Press, 1866, p. 141; Bengal Judicial Proceedings, April 7, 1847, No. 99.

${ }^{22}$ The Trial of Doodoo Meea and His Followers, op. cit., p. 30.

${ }^{23}$ James Wise, Notes on Eastern Bengal, op. cit., p. 23; W. W. Hunter. (1974). A Statistical Account of Bengal, Vol. II. Delhi: India Reprint, pp. 51, 199-200.

${ }^{24}$ From the Magistrate of Jessore, to the Secretary to the Government of Bengal, Fort William, dated Jessore, July 28, 1857. Bengal Judicial Proceedings, August 10, 1857, No. 662.

${ }^{25}$ Calcutta Review, Vol. I, 1844, p. 216.

${ }^{26} \mathrm{Ibid}$. The italics in the above passage appear in the original text.

${ }^{27}$ Ibid.

${ }^{28}$ James Wise, Notes on Eastern Bengal, op. cit., p. 26; Narahari Kaviraj, The Wahabi and Farazi Rebels of Bengal, op. cit., p. 82, 
${ }^{29}$ The Commissioner of Dacca observed that "Bachergunge [Bakerganj] was always noted for turbulent affrays, and when joint magistrate there in 1851, I became well acquainted with the lawlessness of the inhabitants." From F.B.Simson, Commissioner of the Dacca Division, to the Secretary to the Government of Bengal, Judicial Department, No. 336B, dated Dacca, October 11, 1870. Bengal Judicial Proceedings, November 1870, No. 163.

${ }^{30}$ M. A. Khan, History of the Faraidi Movement in Bengal, op. cit; A. R. Mallick, op. cit.; Abdul Bari, "The Reform Movement in Bengal", A History of the Freedom Movement, (1707-1947), Vol. II. (Karachi: 1957), and Jagodish N.Sarkar, Islam in Bengal, op. cit.

${ }^{31}$ Quoted in K. M. Ashraf, "Muslim Revivalists and the Revolt of 1857", P. C. Joshi (Ed.), Rebellion 1857: A Symposium. (Calcutta: 1957), p. 76.

\section{References}

Ahmad, Imtaz. (1966). The Ashraf-Ajlaf dichotomy in India. Indian Economic and Social History Review, iii(3).

Ahmed, Rafiuddin. (1981). The Bengali Muslims-1906: A quest for identity. Delhi: Oxford University Press.

Alavi, Hamza. (1980). India: Transition from feudalism to colonial capitalism. Journal of Contemporary Asia, 10(4), 359-399.

Ashraf, K. M. (1957). Muslim revivalists and the revolt of 1857. P. C. Joshi (Ed.), Rebellion 1857: A Symposium. Calcutta: People' Publishing House.

Baden-Powell, B. H. (1895). Permanent settlement of Bengal. English Historical Review, $x$.

Bandopadhyay, Brajendranath (Ed.). (1940). Sambad Patre Sekaler Katha, Vol. III. Calcutta: Bangiya Sahitya Parishad.

Bari, Abdul. (1957). The reform movement in Bengal. A history of the freedom movement, (1707-1947), Vol. II. Karachi: Pakistan Historical Society.

Bengal Judicial Proceedings. (April 7, 1847). No. 99.

Bengal Judicial Proceedings. (August 10, 1857). No. 662.

Bengal Judicial Proceedings. (March 31, 1859). No. 223. Appendix B.

Bengal Judicial (Criminal) Proceedings. (April 3, 1832). No.6. 
Bengal Judicial Proceedings. (November, 1870). No. 163.

Bengal Judicial (Criminal) Proceedings. (April 30, 1839). Nos. 66-70.

Bengal Judicial (Criminal) Proceedings. (January 23, 1850). Nos. 60-61.

Beveridge, H. (1876). The district of Bakergonj, its history and statistics. London: Trubner, Calcutta Review, I, 1844.

Chatterjee, Bankim Chandra. (1986). Sociological essays: Utilitarianism and positivism in Bengal. Translated and edited by Mukherjee, S.N. and Maddern, Marian. Calcutta: RDDHI.

Choudhury, Nurul H. (2001). Peasant radicalism in nineteenth century Bengal: The Faraizi, Indigo and Pabna Movements. Dhaka: Asiatic Society of Bangladesh.

Day, Lal Behari. (1874). Govinda Samanta or the history of the Bengal Raiyat. London: Macmillan and Company.

Hardy, P. (1972). The muslims of British India. London: Cambridge University Press.

Hunter, W. W. (1871). The Indian Mussalmans. London: Trubner.

(1974). A statistical account of Bengal, Vol. II. Delhi: D. K. Publishing House, Reprint.

Islam, M. Mufakharul. (2012). An economic history of Bengal. 1757-1947. Dhaka: Adorn Books.

Khan, M. A. (1965). History of the Faradi movement in Bengal, 1818-1906. Karachi: Pakistan Historical Society.

(1964). Religious doctrine of the Faraidis. Journal of the Pakistan Historical Society, Vol. XII, Part I.

Kling, B. B. (1966). The blue mutiny: The indigo disturbances in Bengal, 1959-62. Philadelphia: University of Pennsylvania Press.

Mallick, A. R. (1961). British policy and the Muslims in Bengal, 1757-1856. Dacca: Asiatic Society of Pakistan.

Mujeeb, M. (1968). Social reform among Indian Muslims. Delhi: Delhi University. 
Ray, R. (1979). Change in Bengal agrarian society 1760-1850. Delhi: Manohar.

Sarker, J. N. (1967). Islam in Bengal. In N. K. Sinha (Ed.), The history of Bengal (1757-1905). Calcutta: Calcutta University.

Selections from the Records of the Bengal Government Vol. xlii. (1866). Papers Connected with the Trial of Moulvie Ahmedoollah of Patna and Others for Conspiracy and Treason. Calcutta: Alipore Jail Press.

Spear, P. (1984). A history of India, Vol. ii (4th ed.). Middlesex: Penguin Books.

Taylor, J. (1840). A sketch of the topography and statistics of Dacca. Calcutta: Military Orphan Press.

Translation of Proceedings Held in Two Cases Tried in 1847 before the Session Judge of Dacca in which Doodoo Meea and His Followers, Belonging to the Sect of Hadjees or Ferazees were Charged with Unlawful Assemblage, Attended with Wounding, Plunder, Arson \& C. Calcutta: Military Orphan Press, 1848.

Wise, J. (1883). Notes on the races, castes and trades of Eastern Bengal. London: Harrison and Sons.

Wise, J. (1894). The Muhammadans of Eastern Bengal. Journal of Asiatic Society of Bengal, LXIII, Part III, (1). 